\title{
The state of preparedness of prospective physical education and sports teachers
}

\author{
Metin Y1lmaz ${ }^{\mathrm{ABCD}}$, Yunus E. Karakaya ${ }^{\mathrm{ACDE}}$, Yüksel Savucu ${ }^{\mathrm{ADE}}$ \\ Firat University, Turkey
}

Authors contribution: A - Study design; B - Data collection; C - Bibliometric analysis; D - Manuscript preparation; E - Funds collection

\begin{tabular}{|c|c|}
\hline \multicolumn{2}{|l|}{ Abstract } \\
\hline Purpose: & $\begin{array}{l}\text { This study was conducted to determine the state of readiness of prospective physical education and } \\
\text { sports teachers, who were studying in sports education institutions in Turkey. }\end{array}$ \\
\hline Material: & $\begin{array}{l}\text { The sample of the study consisted of } 552 \text { prospective physical education and sports teachers, who were } \\
\text { chosen by the random sampling method. To collect the data from the sample group, the "Preparedness } \\
\text { for Teach Scale", which consisted of } 20 \text { items and } 4 \text { subscales. The collected data were analysed for } \\
\text { normality by using SPSS } 22.0 \text { package software. Because the data demonstrated a normal distribution, } \\
\text { the "Independent Samples t-tests" and "One-way ANOVA tests" were conducted. To determine the level of } \\
\text { relationship between dependent variables, "Pearson Correlation Analysis" was conducted. }\end{array}$ \\
\hline Results: & $\begin{array}{l}\text { In the gender variable of the sample group, statistically significant differences were observed in the } \\
\text { subscales of "Designing the instructional process" and "Understanding the learner". In the grade variable, } \\
\text { significant differences were determined in the subscales of "Forming and effective learning atmosphere", } \\
\text { "Designing the instructional process" and "Techno-pedagogical competence". In the variable of the } \\
\text { department of education, significant differences were determined in all the subscales. Because of the } \\
\text { correlation analysis, it was observed that there were positive and strong correlations between the } \\
\text { subscales of "Forming an effective learning atmosphere" and "Designing the instructional process" (r= } \\
0.807 ; p<0.05) \text {. }\end{array}$ \\
\hline Conclusions: & $\begin{array}{l}\text { For teachers to become more confident in themselves and develop their competencies more positively, it } \\
\text { will be beneficial to enlarge professional standards and teaching framework. Within this scope, considering } \\
\text { the results obtained from the study, it will be beneficial to create positive classroom environments and } \\
\text { to ensure that prospective teachers benefit from teachers' experiences to improve their preparedness } \\
\text { to professional life. The study indicated that the competencies of prospective teachers towards the } \\
\text { profession of teaching were generally positive. It was observed that several factors affected prospective } \\
\text { physical education and sports teachers in their preparedness for teaching. Thus, it is important to ensure } \\
\text { that prospective physical education and sports teachers gain acquisitions for their general competencies } \\
\text { in the profession of teaching before they complete their undergraduate education. }\end{array}$ \\
\hline Keywords: & higher education, sports education, prospective teachers, preparedness, physical education. \\
\hline
\end{tabular}

\section{Introduction}

The advancement and development of societies are rather parallel to the quality of the education they receive. The richness of a country depends on people's effective use and development of their natural skills. Thus, the development of a nation is first the result of people's effort. Finding and using natural resources, turning capital into an investment, developing the technology, producing consumer goods, and maintaining economic relationships require the element of having skilful people. If a country cannot develop its people, it cannot establish anything and cannot sustain itself. In today's societies, when advanced and developed countries are examined, it is observed that both the ratio of the trained people to the society and the period of education with the quality of the education provided are at rather advanced levels. In contrast, in underdeveloped countries, both the ratio of trained people to society and the period of education with the quality of the education provided are observed to be at low levels. Advancements such as gaining the required consciousness to advance, producing technology

(c) Metin Yılmaz, Yunus E. Karakaya, Yüksel Savucu, 2020

doi:10.15561/26649837.2020.0608 and science, and adapting to tomorrow's world quickly are only possible when a certain level of education and training is provided [1].

Unless human behaviors are not changed consistently, namely validly and reliably, the ability of humanity to achieve a long-awaited lifestyle may not be a matter of discussion. Equipping people with consistent behaviors, namely problem-solving knowledge and skills, can be possible with education. This is because the most effective tool to train and channelize labor force resources is education. Teachers constitute one of the most important elements of this tool. Innovations in an education system can only be realized via teachers. No matter how well the programs are designed and the education environments are regulated, all the investment and effort are for nothing unless qualified teachers are trained. No education model can produce a service above the personnel to implement that model. Therefore, a school is only as good as its teachers. Undoubtedly, teachers are professionals who assume sacred roles such as training individuals from all professions required by societies and shaping the future of a nation $[1,2]$. Countries expect incredible achievements 
from their education systems. Some of these include preparing the youth for tomorrow's roles, training them as productive and creative individuals, protecting them from any kind of bad and harmful behaviors, and ensuring that they are trained as good people and citizens [3]. Education systems can produce individuals with such qualities in classroom environments in schools. Undoubtedly, one of the most vital elements of the priorities of this production system is the teachers.

Today, the profession of teaching is a field that requires expert knowledge and experience at social, cultural, economic, scientific, and technological aspects related to education and professional competence [4]. It is of utmost importance to train qualified teachers. The quality of the opportunities provided for prospective teachers cannot solely enable them to become competent in their profession. The attitudes of prospective teachers toward their profession are also important at this point. The attitudes of individuals affect their emotions as well as affecting their thoughts and behaviors. Erdem et al. [5] stated that teachers' development of positive attitudes toward their profession enables them to become more effective while practicing the profession of teaching.

The belief that a strong education is required to set high standards and meet these standards in education resulted in the emergence of ever-increasing demands on teachers [6]. The education received before starting to practice the profession of teaching is viewed as one of the most important steps for prospective teachers to obtain theoretical and practical knowledge [7]. Everywhere in the world, the prospective teachers are expected to possess the required competencies to become an effective teacher and facilitate students' learning because of the preservice education they receive. The most important role of universities, which assume the responsibility of training teachers, to play on this subject is to develop prospective teachers' abilities to view things with a perspective beyond their own, to empathize with students and to understand the meaning of this experience in terms of learning [8-9]. However, the results of the studies related to teacher education, teacher-training programs, and teachers who started serving recently demonstrated that teacher education was not sufficient in providing them with certain competencies. Teacher education programs fall short of providing prospective teachers to acquire knowledge about real school conditions, namely turning theory into practice [10]. Today, there is a preconception about a negative relationship between the preparedness of prospective physical education and sports teachers and the outputs of prospective teachers. The study conducted within this framework aimed to determine the levels of preparedness of prospective physical education and sports teachers, who study in sports education institutions at the higher education level in Turkey. The study is of importance in terms of revealing how prepared do the prospective physical education and sports teachers feel in professional terms and providing professional contributions to teachers and prospective teachers. According to this general aim, answers to the questions, such as "Do the preparedness levels of prospective physical education and sports teachers differ according to the variables of gender, grade level, and department of education?" and "Are there any relationships between the scores of subscales related to the preparedness levels of prospective physical education and sports teachers to teaching?".

\section{Material and Methods}

Participants.

The study group consisted of 552 randomly chosen prospective physical education and sports teachers, who studied at Ağrı İbrahim Çeçen University, Bitlis Eren University, Dicle University, Furat University, Harran University, and İnönü University. The study contained 317 prospective teachers who studied in the department of physical education and sports teaching at the $2^{\text {nd }}, 3^{\text {rd }}$ and $4^{\text {th }}$ grades. The study also included students, who received pedagogical formation at Education Faculties in Turkey, from the departments of Coaching Training (135 students) and Sports Management (100 students). Because the students who study sports education at the $4^{\text {th }}$ grade receive pedagogical formation education at Education Faculties for teaching, they were included in the study. As a result of this education, the students gain the status of a prospective teacher. Because the physical education and sports teaching students at the $1^{\text {st }}$ grade are assumed not ready for teaching, they were not included in the study group. Furthermore, because the students who receive sports education in other departments (Departments of Coaching Training and Sports Management) did not receive a pedagogical formation education $\left(1^{\text {st }}, 2^{\text {nd, }}\right.$ and $3^{\text {rd }}$-grade students), they were not included in the study group.

It was determined that 526 of the prospective teachers included in the study were single while 26 of them were married. When the age variable of the study group was examined, it was observed that 173 prospective teachers were between 19 and 22 years old while 327 prospective teachers were between 23 and 26 years old in addition to 52 prospective teachers who were 27 years old and above. 395 of the prospective teachers stated that they wished to work in the public sector while 157 of them stated that they wished to serve in the private sector.

\section{Research Design.}

\section{Data Collection Tools.}

As the data collection tool in the study, a questionnaire form, which was used in a cooperative study in the city of New York in the USA, was used. This scale is called "Prepared to Teaching Scale (PTS)" and it was adapted into Turkish with validity and reliability studies by Yildırım and Kalman [8]. This scale consisted of 20 items and 4 subscales. The Cronbach alpha reliability coefficient for the 20 items of the scale was calculated as 0.923 . Additionally, the Cronbach alpha reliability coefficient for the subscale of "Forming an effective learning atmosphere (FELA)" was calculated as 0.827 while the Cronbach alpha reliability coefficient for the subscale of "Designing the instructional process (DIP)" 
was calculated as 0.806 in addition to the Cronbach alpha reliability coefficients of 0.838 for the subscale of "Techno-pedagogical competence (TPC)" and the Cronbach alpha reliability coefficient of 0.739 for the subscale of "Understanding the Learner (UL)". This scale form is a self-report form that is scored with a 5-point Likert scale. Each item is evaluated per a 5-point replying system (1: Quite Insufficient - 5: Quite Sufficient).

Statistical Analysis.

In the study, the collected data were analysed by SPSS 22 package software. For the data in the study, a normality test was first conducted to determine whether the "Preparedness to Teaching Scale" and its subscales demonstrated a normal distribution (Table 1).

As a result of the normality analysis, it was determined that the skewness and kurtosis values of the Preparedness to Teaching scale and its subscales were between +1.5 and -1.5 (Table 1). Tabachnick and Fidel [11] stated that the states where kurtosis and skewness values between +1.5 and -1.5 could be interpreted as the presence of normal distribution. For the variables that demonstrate normal distributions, t-test, and one-way variance analyses were conducted. To reveal the sources of significant differences between the variables, LSD tests were conducted. To determine the relationship between the variables, the Pearson correlation analyses were conducted. The relationships between dependent variables were evaluated according to Table 2 [12].

\section{Results}

According to the aims of the study, the findings obtained from the prospective physical education and sports teachers were presented below.

T-tests were conducted to determine whether the "Preparedness to Teaching Scale" and its subscales differed according to the variable of gender. Statistically significant differences were determined in the subscales of "DIP" $(\mathrm{t}=-3.068 ; \mathrm{p}=0.002 ; \mathrm{p}<0.05)$ and " $U L$ " $(\mathrm{t}=$ $-2.684 ; \mathrm{p}=0.007 ; \mathrm{p}<0.05)$. In the other subscales of the "Preparedness to Teaching Scale" (FELA and TPC subscales), no statistically significant difference was observed (Table 3).

Table 1. Results of the normality test for the preparedness to teaching scale and its subscales

\begin{tabular}{llllll}
\hline Scale & PTS & FELA & DIP & TPC & UL \\
& Scale & Subscale & Subscale & Subscale & Subscale \\
\hline $\mathbf{N}$ & 552 & 552 & 552 & 552 & 552 \\
Mean & 3.684 & 3.657 & 3.713 & 3.763 & 3.547 \\
Standard Deviation & 0.680 & 0.724 & 0.776 & 0.797 & 0.836 \\
Skewness & {$[0.558 ; 0.104]$} & {$[-0.486 ; 0.104]$} & {$[-0.598 ; 0.104]$} & {$[-0.556 ; 0.104]$} & {$[-0.452 ; 0.104]$} \\
Kurtosis & {$[0.304 ; 0.208]$} & {$[0.224 ; 0.208]$} & {$[0.108 ; 0.208]$} & {$[0.251 ; 0.208]$} & {$[-0.038 ; 0.208]$} \\
\hline
\end{tabular}

Table 2. Values regarding the correlation levels between the dependent variables

\begin{tabular}{ll}
\hline $\mathbf{r}$ & Correlation Level \\
\hline $0.00-0.25$ & Rather Weak \\
$0.26-0.49$ & Weak \\
$0.50-0.69$ & Moderate \\
$0.70-0.89$ & Strong \\
$0.90-1.00$ & Rather Strong \\
\hline
\end{tabular}

Table 3. The results of the t-test conducted to determine whether there were differences among the study group according to the variable of gender

\begin{tabular}{|c|c|c|c|c|c|c|}
\hline Scale & Variable & $\mathbf{N}$ & $\overline{\mathbf{x}}$ & Sd & t-Value & p-Value \\
\hline \multirow[t]{2}{*}{ FELA Subscale } & Male & 362 & 3.624 & 0.694 & \multirow{2}{*}{-1.485} & \multirow{2}{*}{0.138} \\
\hline & Female & 190 & 3.721 & 0.777 & & \\
\hline \multirow[t]{2}{*}{ DIP Subscale } & Male & 362 & 3.640 & 0.772 & \multirow{2}{*}{-3.068} & \multirow{2}{*}{$0.002 *$} \\
\hline & Female & 190 & 3.852 & 0.766 & & \\
\hline \multirow[t]{2}{*}{ TPC Subscale } & Male & 362 & 3.715 & 0.817 & \multirow{2}{*}{-1.941} & \multirow{2}{*}{0.053} \\
\hline & Female & 190 & 3.853 & 0.751 & & \\
\hline \multirow[t]{2}{*}{ UL Subscale } & Male & 362 & 3.478 & 0.839 & \multirow{2}{*}{-2.684} & \multirow{2}{*}{$0.007^{*}$} \\
\hline & Female & 190 & 3.678 & 0.818 & & \\
\hline
\end{tabular}

$* p<0.05$ 
Statistically significant differences were determined between $3^{\text {rd }}$-grade and $4^{\text {th }}$-grade prospective teachers in the subscales of "FELA", "DIP" and "TPC". In the subscale of " $U L$ ", no significant difference was observed (Table 4).

Variance analyses were conducted to determine whether the subscales of the "Preparedness to Teaching Scale" significantly different according to the variable of the department of education (Table 5). In the "FELA" subscale, statistically significant differences were determined between the students of the department of Physical Education and Sports Teaching and the students of the departments of Sports Management and Coaching Training. In the "DIP" subscale, statistically significant differences were determined between the students of the department of Coaching Training and the students of the departments of Physical Education and Sports
Teaching and Sports Management. In the " $T P C$ " subscale, statistically significant differences were determined between the students of the department of Coaching Training and the students of the departments of Physical Education and Sports Teaching and Sports Management. In the " $U L$ " subscale, statistically significant differences were determined between the students of the department of Physical Education and Sports Teaching and the students of the departments of Sports Management and Coaching Training.

Positive and strong correlations were determined between the subscales of "FELA" and "DIP" $(\mathrm{r}=0.807$; $\mathrm{p}<0.05$ ). The weakest correlation between the subscales of the scale was determined between the subscales of "TPC" and " $U L "$, which was positive and at a moderate level.

Table 4. The results of the one-way variance analysis conducted to determine whether the scores of the study group differed according to the variable of grade of education

\begin{tabular}{llllllll}
\hline Scale & Variable & $\mathbf{N}$ & $\overline{\mathbf{X}}$ & $\mathbf{S d}$ & $\mathbf{F}$ & $\mathbf{p}$-Value & LSD \\
\hline \multirow{4}{*}{ FELA Subscale } & (a) $2^{\text {nd }}$ Grade & 90 & 3.716 & 0.673 & & & \\
& (b) $3^{\text {rd }}$ Grade & 327 & 3.577 & 0.724 & 5.593 & $\mathbf{0 . 0 0 4}$ & b, c \\
& (c) $4^{\text {th }}$ Grade & 135 & 3.814 & 0.734 & & & \\
\hline \multirow{4}{*}{ DIP Subscale } & (a) $2^{\text {nd }}$ Grade & 90 & 3.774 & 0.785 & & & \\
& (b) $3^{\text {rd }}$ Grade & 327 & 3.635 & 0.781 & 4.544 & $\mathbf{0 . 0 1 1 ^ { * }}$ & b, c \\
& (c) $4^{\text {th }}$ Grade & 135 & 3.864 & 0.735 & & & \\
TPC Subscale & (a) $2^{\text {nd }}$ Grade & 90 & 3.788 & 0.743 & & & \\
& (b) $3^{\text {rd }}$ Grade & 327 & 3.697 & 0.822 & 3.270 & $\mathbf{0 . 0 3 9 *}$ & b, c \\
& (c) $4^{\text {th }}$ Grade & 135 & 3.903 & 0.755 & & & \\
UL Subscale & (a) $2^{\text {nd }}$ Grade & 90 & 3.540 & 0.737 & & & \\
& (b) $3^{\text {rd }}$ Grade & 327 & 3.494 & 0.840 & 2.404 & 0.091 & - \\
\hline
\end{tabular}

$* p<0.05$

Table 5. The results of the one-way variance analysis conducted to determine whether the scores of the study group differed according to the variable of department of education

\begin{tabular}{|c|c|c|c|c|c|c|c|}
\hline Scale & Variable & $\mathbf{N}$ & $\bar{x}$ & Sd & $\mathbf{F}$ & p-Value & LSD \\
\hline & (a) Physical Education and Sports Teaching & 317 & 3.746 & 0.716 & & & $a \mathrm{~h}$ \\
\hline \multirow[t]{3}{*}{ FELA Subscale } & (b) Sports Management & 100 & 3.455 & 0.697 & 6.820 & $0.001 *$ & \\
\hline & (c) Coaching Training & 135 & 3.601 & 0.732 & & & $a, c$ \\
\hline & (a) Physical Education and Sports Teaching & 317 & 3.760 & 0.745 & & & \\
\hline \multirow[t]{3}{*}{ DIP Subscale } & (b) Sports Management & 100 & 3.490 & 0.807 & 5.157 & $0.006 *$ & \\
\hline & (c) Coaching Training & 135 & 3.770 & 0.799 & & & $c, b$ \\
\hline & (a) Physical Education and Sports Teaching & 317 & 3.818 & 0.782 & & & $c, a$ \\
\hline \multirow[t]{3}{*}{ TPC Subscale } & (b) Sports Management & 100 & 3.506 & 0.806 & 6.478 & $0.002 *$ & $c, b$ \\
\hline & (c) Coaching Training & 135 & 3.822 & 0.793 & & & \\
\hline & (a) Physical Education and Sports Teaching & 317 & 3.633 & 0.804 & & & \\
\hline \multirow[t]{2}{*}{ UL Subscale } & (b) Sports Management & 100 & 3.303 & 0.878 & 6.056 & $0.003^{*}$ & \\
\hline & (c) Coaching Training & 135 & 3.528 & 0.849 & & & a, c \\
\hline
\end{tabular}

$* p<0.05$ 
Table 6. The results of the correlation analysis between the subscales of the preparedness to teaching scale

\begin{tabular}{llllll}
\hline Scale & Descriptive Values & $\mathbf{1}$ & $\mathbf{2}$ & $\mathbf{3}$ & $\mathbf{4}$ \\
\hline \multirow{3}{*}{ FELA Subscale (1) } & $\mathbf{r}$ & 1 & & & \\
& $\mathbf{p}$ & - & & & \\
& $\mathbf{N}$ & 552 & & & \\
\hline & $\mathbf{r}$ & $\mathbf{0 . 8 0 7 ^ { * }}$ & 1 & & \\
DIP Subscale (2) & $\mathbf{p}$ & 0.000 & - & & \\
& $\mathbf{N}$ & 552 & 552 & & \\
& $\mathbf{r}$ & $0.634^{*}$ & $0.656^{*}$ & 1 & \\
TPC Subscale (3) & $\mathbf{p}$ & 0.000 & 0.000 & - & \\
& $\mathbf{N}$ & 552 & 552 & 552 & \\
\hline & $\mathbf{r}$ & $\mathbf{0 . 7 2 3 ^ { * }}$ & $0.696^{*}$ & $0.571^{*}$ & 1 \\
UL Subscale (4) & $\mathbf{p}$ & 0.000 & 0.000 & 0.000 & - \\
& $\mathbf{N}$ & 552 & 552 & 552 & 552 \\
\hline
\end{tabular}

$* p<0.05$

\section{Discussion}

According to the results of this study, which aimed to determine the state of preparedness to the teaching of prospective physical education and sports teachers in six different universities in Turkey, in terms of the variable gender, the female prospective teachers stated more positive perceptions in the subscales of "DIP" and " $U L$ " compared to male prospective teachers (Table 3 ). Within this scope, it can be stated that female prospective teachers are more ready for the profession of teaching. This situation can also indicate that female prospective teachers are more inclined to the profession of teaching. It can be interpreted that female prospective teachers internalized the profession of teaching more. Some of the studies in the literature support this interpretation [13-19]. Doğan and Çoban [20] stated that the interest of females in the profession of teaching was higher compared to males while reporting that the profession of teaching is regarded as a profession for females according to the culture of the society in Turkey, interpreting that females internalized this thought. However, several studies were observed to report different conclusions. Hacı̈̈meroğlu and Taşkın [21] conducted a study with prospective teachers and did not determine any significant difference in terms of the variable of gender. In a study that investigated the attitudes of prospective teachers toward the profession of teaching, Şahin [22] reported that there was no statistically significant difference between the attitudes of female and male prospective teachers toward the profession of teaching. Furthermore, when various studies were examined, no statistically significant difference was observed between female and male prospective teachers [23-27].

According to the study group's variable of the department of education, significant differences were determined in the subscales of FELA, DIP, and TPC.
In these subscales, it was observed that the prospective teachers studying at the $4^{\text {th }}$ grade reported more positive perceptions compared to the prospective teachers studying at other grades. The fact that the preparedness to teaching levels of prospective teachers at the $4^{\text {th }}$ grade was at higher levels was believed to be due to reasons such as receiving more sports education and being in the process of graduation (Table 4). In several studies, the attitudes of prospective teachers toward prospective teachers demonstrated differences according to the level of grade [28-31]. Rajić et al. [9] reported that prospective teachers generally had more developed professional skills in recent years. Göktaş [32] stated that the mean scores of attitudes toward the profession of students at the $1^{\text {st }}$ grade were lower compared to the mean scores of the students at the $2^{\text {nd }}, 3^{\text {rd }}$ and $4^{\text {th }}$ grades. It was observed that the attitudes of students toward the profession of teaching were higher at higher grades. In another study, Özder et al. [33] determined that there was no significant difference in terms of the variable of grade. Pehlivan [34] determined that the attitudes of prospective physical education and sports teachers at the last grade were low and stated that this was due to their concerns about finding a job. Sağlam [35] determined statistically significant differences in the variable of grade. Uğurlu and Polat [11] reported that there were significant differences between the prospective teachers at the $1^{\text {st }}$ grade and the $2^{\text {nd }}$ grade. In another study, Gökçe and Sezer [14] reported that there was no significant difference in the attitudes of prospective teachers toward the profession of teaching according to the variable of grade.

According to the study group's department of education, in the subscales of "FELA" and " $U L "$, statistically significant differences were determined between the students of the department of Physical Education and Sports Teaching and the students of Sports 
Management and Coaching Training. It was observed that the preparedness levels of the students, who studied in the department of Physical Education and Sports Teaching, were more positive. In the subscales of "DIP" and "TPC", statistically significant differences between the students of the department of Coaching Training and the departments of Physical Education and Sports Teaching and Sports Management. It was determined that the levels of preparedness to the teaching of the students of the department of Coaching Training were more positive (Table 5). According to these findings, it can be stated that the levels of preparedness to the teaching of the students studying in the departments of Physical Education and Sports Teaching and Coaching Training were at better levels compared to the prospective teachers at the department of Sports Management. Additionally, these findings can indicate that the variable of the department is an effective factor in becoming a physical education and sports teacher. In parallel with these findings, in a study conducted by Kartal and Afacan [36] it was reported that there were significant differences between the variables of the department of education in prospective teachers. In a study conducted by Azar [37], it was reported that the department of education was a significant factor in this subject. Engin and Koç [38] determined that there were differences in the last grade students at the faculty of education according to the undergraduate program of education. In the study, no statistically significant difference was determined in the subscale of technopedagogical competence. Several studies also reported contrary findings [5, 24, 39, 40, 42, 43].

It was observed that there was a positive and strong correlation between the subscales of "FELA" and "DIP" $(\mathrm{r}=0.807 ; \mathrm{p}<0.05)$. The weakest correlation was determined between the subscales of "TPC" and " $U L$ ", which was positive and at a moderate level (Table 6). Macun et al. [43] investigated the self-sufficiency levels and preparedness to profession levels of prospective teachers and determined that there were moderate and positive correlations between the levels of planning and developing teaching, forming a positive classroom environment, effective learning process, individual differences, academic development self-sufficiencies, and the levels of preparedness to professional life. According to this result, it was interpreted that as the self-sufficiency levels of prospective teachers increased, their levels of preparedness to professional life also increased.

\section{Conclusion}

The problem of today is training great teachers. Therefore, teaching is a profession of special expertise as well as an art. Because good education is provided by good teachers. Teachers who know about the needs of the society where they live, who are aware of their capacities, who can be active in teaching, who possess suitable characteristics for teaching, and who have a command of their field will achieve the identity of a teacher. For teachers to become more confident in themselves and develop their competencies more positively, it will be beneficial to enlarge professional standards and teaching framework. Within this scope, considering the results obtained from the study, it will be beneficial to create positive classroom environments and to ensure that prospective teachers benefit from teachers' experiences to improve their preparedness to professional life. The study indicated that the competencies of prospective teachers towards the profession of teaching were generally positive. It was observed that several factors affected prospective physical education and sports teachers in their preparedness for teaching. Thus, it is important to ensure that prospective physical education and sports teachers gain acquisitions for their general competencies in the profession of teaching before they complete their undergraduate education. By this means, qualified individuals who can increase the quality of sports education can be trained. In conclusion, practices that can increase the level of preparedness to teach prospective teachers can be implemented. Interactions between successful physical education and sports teachers, who still serve in education, and prospective physical education and sports teachers, who continue their undergraduate education, can be organized within the scope of "good examples in education". This study has several limitations. The study was conducted only with six universities. The number of participants in the study can be increased.

\section{Acknowledgment}

Thank you to the students who participated in the research. There is no financial support in the research.

\section{Conflict of interest}

The authors declare that there is no conflict of interests.

\section{Note}

A part of this study was verbally presented as a conference paper in the 16th International Sports Sciences Congress "Sports Sciences for Sustainable Success", conducted between 31 October-03 November 2018 in Antalya. 


\section{References}

1. Gür K. Observation of Anatolian teacher training high schools and Anatolian high schools students' attitudes for profession of teaching (Konya city sample). [Master Thesis]. Konya: Selcuk University Institute of Social Sciences; 2010.

2. Kuran K. Öğretmenlik mesleğine giriş [Introduction to teaching profession]. Printing. Ankara: Pegem Publishing; 2002. (In Turkish).

3. Balc1 A, Pehlivan Aİ. Eğitim yönetimi [Education management]. Ankara: Publications of the Ministry of Education; 2001. (In Turkish).

4. Recepoğlu E. Analyzing the relationship between prospective teachers' life satisfaction and attitudes concerning teaching profession. Hacettepe University Journal of Education Special Issue, 2013; (1): 311-326.

5. Erdem AR, Gezer K, Çokadar H. Ortaöğretim fenmatematik ve sosyal alanlar öğretmenliği tezsiz yüksek lisans öğrencilerinin öğretmenlik mesleğine ilişkin tutumları [Attitudes of the students of non-thesis master's program in secondary education science-math and social sciences teaching towards the profession of teaching). 14 Ulusal Eğitim Bilimleri Kongresi Bildiri Kitabl, [14 Proceedings Books of National Educational Sciences Congress) Denizli; 2005. P. 471-477. (In Turkish).

6. Darling-Hammond L. Constructing 21st-century teacher education.JournalofTeacherEducation.2006;57(3):300-314. https://doi.org/10.1177/0022487105285962

7. Özoğlu M, Gür BS, Altunoğlu A. Türkiye ve dünyada ögretmenlik: retorik ve pratik [Teaching in Turkey and The World: Rhetoric and Practice). Ankara: Education Bir Sen Publishing; 2013. (In Turkish).

8. Yıldırım İ, Kalman M. The validity and reliability study of the Turkish version of the preparedness to teach scale. Kastamonu Education Journal, 2017; 25 (6): 2311-2326.

9. Rajić V,Hoşgörür T, Drvodelić M. An international perspective on the teacher qualities issue: The case of Croatia and Turkey. Croatian Journal of Education, 2015; 17 (1): 37- 62. https://doi.org/10.15516/cje.v17i1.817

10.Gökmenoğlu T. Preparing teachers: expectations and existing situation at faculties of education. Turkish Online Journal of Qualitative Inquiry, 2013; 4 (4): 39-54.

11. Tabachnick BG. Fidell LS. Using multivariate statistics. Allyn \& Bacon, Pearson Education; 2007.

12.Kalaycı Ş. SPSS uygulamalı çok değişkenli istatistik teknikleri [SPSS applied multivariate statistical techniques). Ankara: Asil Publ.; 2006. (In Turkish).

13. Y1ldırımE. Theinvestigationof theteachercandidates'attitudes towards teaching profession according to their demographic variables (The sample of Maltepe University). ProcediaSocial and Behavioral Sciences, 2012; 46: 2352-2355. https://doi.org/10.1016/j.sbspro.2012.05.483

14.Gökçe F, Sezer GO. The attitudes of student teachers towards teaching profession. Journal of Uludağ University Education Faculty, 2012; 25 (1): 1-23.

15.Uğurlu CT, Polat $\mathrm{S}$. The attitudes of elementary education students towards teaching profession. University of Cumhuriyet, Faculty of Sciences and Arts. Journal of Social Sciences, 2011; 35 (1): 68-74.

16.Akkaya N. An investigation of prospective teachers' attitudes regarding teaching various in terms of variables. Buca Ĕgitim Fakültesi Dergisi, 2009; 25: 35-42.

17.Baykara PK. A study on pre-service classroom teachers' socio-cultural properties and their attitudes toward teaching occupation as a subject. Mersin University Journal of the Education, 2008; 4 (2): 151-168.

18.Özdemir SM. An investigation of prospective primary teachers' self-efficacy beliefs regarding teaching process in terms of certain variables. Educational Administration: Theory and Practice, 2008; 54, 277-306.

19.Coultas CJ, Lewin KW. Who becomes a teacher? the characteristics of student teachers in four countries. International Journal of Educational Development, 2002; $22 \quad$ (3-4): $243-260$. https://doi.org/10.1016/S0738-0593(01)00066-9

20.Doğan T, Çoban AE. The investigation of the relations between students' attitude toward teaching profession and anxiety level in faculty of education. Education and Science, 2009; 34 (153): 157-168.

21.Hacıömeroğlu G, Taşkın ÇŞ. Preservice teachers' attitudes towards teaching profession in primary and secondary education. Ahi Evran Üniversitesi Kırşehir Eğitim Fakültesi Dergisi, 2010;11 (1): 77-90.

22.Sahin FG. Teacher candidates' attitudes towards teaching profession and life satisfaction levels. ProcediaSocial and Behavioral Sciences, 2010; 2: 5196- 5201. https://doi.org/10.1016/j.sbspro.2010.03.845

23.Engin G, Koç GÇ. The attitudes of prospective teachers towards teaching (the case of ege university, faculty of education). Türkiye Sosyal Araştırmalar Dergisi, 2014; 18 (2): 153-168.

24.Yenice, N. Investigating the self-efficacy and problem solving skills of pre-service teachers. Electronic Journal of Social Sciences, 2012; 39: 36-58.

25.Ak1llı M, Seven S. An investigation of prospective science teachers' attitudes towards the profession of teaching. Inönü Universitesi Eğitim Fakültesi Dergisi, 2010; 11 (3): 61-73.

26.Oğuz A, Topkaya N. Ortaöğretim alan öğretmenliği öğrencilerinin öğretmen öz-yeterlik inançları ile öğretmenliğe ilişkin tutumları [Secondary field of teacher attitudes to teaching students of teacher self-efficacy beliefs). Akademik Bakıs. 2008; 14: 23-36. (In Turkish).

27.Ekici G. The effects of the classroom management lesson on preservice teachers' teacher sense of self-efficacy. Journal of Education, 2008; 35: 98-110.

28.Açış1 $\mathrm{S}$, Kolomuç A. Study of the would-be class teachers' attitude towards the profession. Journal of Research in Education and Teaching, 2012; 1(2): 266-271.

29.Tekerek M, Polat S. Preservice teachers attitudes towards teaching profession. 5th International Computer \& Instructional Technologies Symposium. Elazığ: Firat University, 22-24 September; 2011. P.100-106.

30.Pehlivan KB. A study on pre-service classroom teachers' socio-cultural properties and their attitudes toward teaching occupation as a subject. Mersin Universitesi, Eğitim Fakültesi Dergisi, 2008; 4 (2): 151-168.

31.Çapa Y, Çil N. Öğretmen adaylarının öğretmenlik mesleğine yönelik tutumlarının farklı değişkenler açısından incelenmesi [Investigation of attitudes of prospective teachers toward the profession of teaching according to different variables]. Journal of Faculty of Education, 2000; 18: 69-73. (In Turkish).

32.Göktaş Z. Pre-service teachers' attitudes towards teaching profession in the school of physical education and sports at Balikesir University. The Journal of International Social Research, 2017;10 (51): 1288-1295. https://doi.org/10.17719/jisr.2017.1856

33.Özder H, Konedralı G, Zeki CP. Öğretmen adaylarının öğretmenlik mesleğine yönelik tutumlarının çeşitli değişkenler açısından incelenmesi [Investigation of preservice teachers' attitudes towards teaching profession in terms of various variables]. Educational Administration: Theory and Practice, 2010; 16 (2): 253-275. (In Turkish). 
34.Pehlivan Z. Analysis of physical self-perceptions of physical education teacher candidates and their attitudes toward teaching profession. Education and Science, 2010; 35 (156): 126-141.

35.Sağlam ÇA. The attitudes of the branch of music students toward the teaching profession. Yüzüncü Yll Universitesi, Eğitim Fakültesi Dergisi. 2008; 5 (1): 59-69.

36.Kartal T, Afacan Ö. Examining attitudes of prospective teachers who took pedagogical formation education towards teaching profession. Mehmet Akif Ersoy University, Journal of Education Faculty, 2012; 24: 76-96.

37.Azar A. In-service and pre-service secondary science teachers self-efficacy beliefs about science teaching. Educational Research and Reviews, 2010; 5(4): 172-185. https://doi.org/10.5897/ERR09.243

38.Engin G, Koç GÇ. The attitudes of prospective teachers towards teaching (the case of ege university, faculty of education). Türkiye Sosyal Araştırmalar Dergisi, 2014; 18 (2): 153-168.

39.Sandıkçı M, Öncü E. Determination and comparison of physical education and the other pre-service teachers' self- efficacy beliefs and attitudes toward teaching profession. Pamukkale Journal of Sport Sciences, 2013; 4 (1): 135-151.

40.Ekinci H. Comparison of self-efficacy perceptions of the teacher candidates: music, art and physical education. International Periodical for The Languages, Literature and History of Turkish or Turkic, 2013; 8 (3): 189-196. https://doi.org/10.7827/TurkishStudies.4582

41.Elkatmış M, Demirbaş M, Ertuğrul N. Self-effıcacy beliefs of students who take the pedagogic training program in the faculty of arts and sciences and students in the education faculty towards teaching profession. Pegem Journal of Education \& Instruction, 2013; 3 (3): 41-50. https://doi.org/10.14527/C3S3

42.Çapri B, Çelikkaleli Ö. Investigation of preservice teachers' attitudes towards teaching and professional self-efficacy beliefs according to their gender, programs, and faculties. Inönü Universitesi Eğitim Fakültesi Dergisi, 2008; 9 (15): 33-53.

43.Macun BK, Macun B, Safal1 S. Investigation of teacher selfefficacy levels of teacher candidates and readiness levels for business life. Uluslararası Türkçe Edebiyat Kültür Eğitim Dergisi, 2019; 8 (1): 549-567.

\section{Information about the authors:}

Metin Yılmaz; (Corresponding author); https://orcid.org/0000-0001-8191-7264; metin.yilmaz@firat.edu.tr; Firat University Faculty of Sport Sciences; Elazığ, Turkey.

Yunus E. Karakaya; https://orcid.org/0000-0002-9858-2103; emrekarakaya@firat.edu.tr; Firat University Faculty of Sport Sciences; Elazığ, Turkey.

Yüksel Savucu; https://orcid.org/0000-0002-2749-6806; ysavucu@firat.edu.tr; Fırat University Faculty of Sport Sciences; Elazığ, Turkey.

Cite this article as:

Yılmaz M, Karakaya YE, Savucu Y. The state of preparedness of prospective physical education and sports teachers. Pedagogy of Physical Culture and Sports, 2020;24(6):323-330.

https://doi.org/10.15561/26649837.2020.0608

This is an Open Access article distributed under the terms of the Creative Commons Attribution License, which permits unrestricted use, distribution, and reproduction in any medium, provided the original work is properly cited (http://creativecommons.org/licenses/by/4.0/deed.en).

Received: 18.05 .2020

Accepted: 24.06.2020; Published: 30.12 .2020 